African Crop Science Journal by African Crop Science Society is licensed under a Creative Commons Attribution 3.0 Uganda License. Based on a work at www.ajol.info/ and www.bioline.org.br/cs DOI: http://dx.doi.org/10.4314/acsj.v24i4.6

\title{
IN VITRO PROPAGATION OF THREE COMMERCIAL PASSIONFRUIT VARIETIES IN UGANDA
}

\author{
S.B. MUKASA ${ }^{1}$, A. SSAMULA ${ }^{1,2}$, P. ASAMI ${ }^{2}$ and T.A. HOLTON ${ }^{2}$ \\ ${ }^{1}$ School of Agricultural Sciences, College of Agricultural and Environmental Sciences, Makerere University, \\ P. O. Box 7062 Kampala, Uganda \\ ${ }^{2}$ Biosciences Eastern and Central Africa, International Livestock Research Institute, P. O. Box 30709, \\ Nairobi 00100, Kenya \\ Corresponding author: sbmukasa@ caes.mak.ac.ug, sbmukasa@yahoo.com
}

(Received 6 October, 2015; accepted 26 October, 2016)

\begin{abstract}
Small purple (Passiflora edulis f. edulis) and yellow (P. edulis f. flavicarpa) and KPF 4 (a cross between the two varieties) passionfruit varieties are of high economic importance in Uganda. Production of passionfruit is greatly constrained by viral diseases, leading to significant yield losses. This is aggravated by lack of adequate quantities of clean planting material. In vitro propagation through nodal sections is one way that has been successful in rapidly producing planting materials of vegetatively propagated crops that are clean and true-to-type. This study was aimed at obtaining optimum in vitro growth conditions for rapid micropropagation of the commercial passionfruit varieties in Uganda. Surface sterilised nodal sections from two month old plants were used as explants. For shoot regeneration, explants were cultured on Murashige and Skoog (MS) media, supplemented with varying concentrations of 6-Benzylaminopurine (BAP), either singly or in combination with Kinetin (KIN). Rooting MS media was fortified with varying concentrations of 1-Naphthalene acetic acid (NAA), either singly or in combination with BAP. MS medium supplemented with a combination of $2 \mathrm{mg} \mathrm{l}^{-1} \mathrm{BAP}$ and $0.5 \mathrm{mg} \mathrm{l}^{-1} \mathrm{KIN}$, optimally supported shoot regeneration of the three passionfruit varieties. The average number of shoots and shoot height were 3.3 and $3.1 \mathrm{~cm}$, respectively. Optimal root development was observed on MS media containing $3 \mathrm{mg} \mathrm{l}^{-1} \mathrm{NAA}$, with a mean number of 5.5 leaves and a length of $2.4 \mathrm{~cm}$. The rooted in vitro plantlets were successfully established in a potting mixture containing loam soil and manure in ratio of 1:1.
\end{abstract}

Key Words: 6-Benzylaminopurine, Kinetin, shoot regeneration

\section{RÉSUMÉ}

Les variétés de fruit de la passion petit violet (Passiflora edulis f. edulis), jaune (P. edulis f. flavicarpa) et KPF 4 (croisement réalisé entre les deux variétés précédentes) sont d'une importance économique très élevée en Ouganda. La production du fruit de la passion est sujette à aux maladies virales, causant d'énormes pertes de rendement. Ceci est aggravé par l'inexistence en quantité suffisante des semences de qualité. La propagation In vitro au moyen des sections nodales, est un procédé qui a connu du succès dans la production rapide des semences de bonne qualité chez les plantes à propagation vegetative. La présente étude a été réalisée afin de déterminer les conditions optimales de croissance in vitro en vue d'une micropropagation rapide des variétés commerciales de fruit de la passion en Ouganda. Des sections nodales prélevées sur des plants de fruit de la passion ages de deux mois, ont été stérilisées en surface et utilisées comme explants. Pour la régénération plantulaire, les explants ont été cultivés sur des milieu de culture Murashige et Skoog (MS), additionnés de diverses concentrations de 6Benzylaminopurine (BAP), soit uniquement ou en combinaison avec de la Kinetine (KIN). Le milieu de culture MS pour la croissance racinaire a été renforcé avec diverses concentrations de 1-Naphthalene acide acétique 
(NAA), soit uniquement ou en combinaison avec BAP. Le milieu MS additionné de $2 \mathrm{mg} 1-1$ BAP et $0,5 \mathrm{mg} \mathrm{l}^{-1}$ $\mathrm{KIN}$, a permis une régénération optimale des explants des trois variétés testées. Le nombre moyen de plantule et la longueur des racines étaient respectivement de 3,3 et $3,1 \mathrm{~cm}$. Un développement racinaire optimal a été observe sur milieu MS contenant $3 \mathrm{mg} \mathrm{l}^{-1} \mathrm{NAA}$, avec une moyenne de 5,5 feuilles et une longueur moyenne de 2,4 cm. les plantules in vitro ont repiquées sur pots contenant un mélange de sol argileux et de la fumure dans des proportions $1: 1$.

Mots Clés: 6-Benzylaminopurine, Kinetine, régénération racinaire

\section{INTRODUCTION}

Passionfruits belong to the family Passifloraceae, consisting of about 600 species. Of these species, Passiflora edulis has been extensively used commercially for its fruits (Joy, 2010). In Uganda, three varieties are of high economic significance, namely, Small purple (Passiflora edulis f. edulis), Yellow (Passiflora edulis f. flavicarpa) and KPF 4 (a cross between edulis and flavicarpa) (Ssemwanga, 2007). In Uganda, passionfruits are traded as fresh fruits, supplied to local juice processing companies and also exported (Ssemwanga, 2007). Passionfruits are also used for production of syrups for the pharmaceutical and beverage industry used internationally. Although Ssemwanga (2007) costed a kilogramme of passionfruit at US\$ $0.18-0.50$, other reports put the lowest value of passionfruit at US\$ 1 per kilogramme (Senyonyi, 2014). A farmer in Uganda cultivating a hectare can harvest $100 \mathrm{~kg}$ of passion fruit per week and earn $\$ 200$ - 400 weekly (Senyonyi, 2014). This makes passionfruit a good income earner for farmers in Uganda, particularly since it can be grown in all agro-ecological zones of the country (Ssemwanga, 2007).

Passionfruit production is greatly constrained by viral diseases (Carrero et al., 2013; Wangungu et al., 2014). Viral diseases can easily spread throughout the vineyard, and can lead to significant yield losses (Mbaka et al., 2006). This means that farmers need to frequently plant new and clean fields to maintain good production. Despite biotic factors limiting production, farmers continue to be interested in growing the crop due to the potentially high returns from the venture (Senyonyi, 2014). This, in turn has created a shortage of planting materials. Efforts to alleviate this shortage have been envisaged through the provision of grafted material
(Ssemwanga, 2007) in which the Yellow variety is used as root stock and Small purple as scion. This is because the Yellow passionfruit variety is tropical or near tropical, and thus, is tolerant to environmental stresses like soil-borne diseases; while Small purple is subtropical and is strongly affected by soil-borne diseases (Morton, 1987). However, grafting can potentially introduce systemic infections (Wesonga et al., 2002), which can be spread to farmers' fields. Hybrid varieties have also been used in passionfruit production. However, given that some farmers replant passionfruit using seeds, segregation occurs (Joy, 2010), and thus change in variety purity or integrity. All these conventional methods have not been sufficient to provide enough planting materials of good genetic purity to satisfy the ever increasing demand from existing and new farmers.

In vitro propagation is a means that allows clonal production of plantlets that are true-totype (George, 1996) and has been exploited in many vegetatively propagated crops (Akin-Idowu et al., 2009). Additionally, in vitro propagation provides an avenue for disease screening and multiplication of disease free planting materials (Brown and Thorpe, 1995). Since in vitro methods such as somatic embryogenesis can potentially lead to somaclonal variations, micropropagation using shoot tips or auxillary buds can eliminate this undesirable incidence (Nehra and Kartha, 1994). Marcin and Barbara (2013) reported micropropagation for Passiflora spp of medicinal plants. However, given the species and/or variety-specific response to in vitro culture media and conditions (Drew, 1991, Amugune, 1993; Arinaitwe, 2008; Marcin and Barbara, 2013), it is appropriate to optimize a system for production of commercial varieties. Therefore, the aim of this study was to determine optimum in 
vitro growth conditions for micropropagation of the three commercial passionfruit varieties in Uganda.

\section{MATERIALS AND METHODS}

Explant preparation. Mature seeds were extracted from ripe healthy fruits of Small purple, Yellow and KPF 4 passionfruit varieties, from plants grown in the screenhouse at Makerere University Agricultural Research Institute Kabanyolo, Uganda. To break dormancy, the seeds were soaked in water at room temperature, for $24 \mathrm{hr}$ prior to sowing in a sterile loam and manure soil mixture. This was done in a greenhouse at the International Livestock Research Institute (ILRI), Nairobi, Kenya. Explants were obtained from two-month old stem cuttings, by removing the leaves using a sterile surgical blade. The explants (auxillary buds) of the three varieties were used as starting materials. The explants were surface sterilised by washing in running tap water for 10 mins. In a laminar flow hood, $70 \%$ absolute ethanol was added and swirled for 2 minutes. After pouring off the ethanol, the explants were rinsed three times with distilled sterile water. This was followed by adding $15 \%$ commercial hypochlorite solution $(3.78 \%$ Chlorine) and swirling four consecutive times for 20 minutes. The hypochlorite solution was poured off and explants were rinsed four times with distilled sterile water.

Culture medium and in vitro culture. Murashige and Skoog (MS) (1962) basal media, containing sucrose $(3 \%)$ and gelrite $(0.3 \%)$, was used in auxillary bud culture (through nodal sections) for optimization of rapid propagation of the three popular passionfruit varieties in Uganda. Regeneration medium was supplemented with plant growth regulators namely, 6-benzylamino purine (BAP) at 1, 2 and $3 \mathrm{mg} \mathrm{l}^{-1}$ (singly) and similar concentrations each in combination with $0.5 \mathrm{mg} \mathrm{l}^{-1}$ Kinetin (KIN). Root induction MS medium was supplemented with 1-naphthalene acetic acid (NAA), at 1, 2 and $3 \mathrm{mg} \mathrm{l}^{-1}$ either singly or in combination with varying concentrations of BAP. Concentrations of BAP used were 0.2, 0.4 and $0.6 \mathrm{mg} \mathrm{l}^{-1}$. The control medium did not contain any growth regulators for both experiments.

For in vitro initiation of cultures, the explants were dissected into nodal sections and placed vertically on solidified regeneration medium in test tubes. They were incubated in a growth room conditioned at temperature $25-27^{\circ} \mathrm{C}$ and $75-80 \%$ relative humidity, at $16 \mathrm{hr}$ photoperiod with cool fluorescent light $\left(100 \mu \mathrm{mol} \mathrm{m}^{-2} \mathrm{~s}^{-1}\right)$ and $8 \mathrm{hr}$ dark conditions. Developed shoots were sub-cultured twice before transferring the cultures to root induction media.

Experimental setup. The experiment was set up in a completely randomised design. For shoot regeneration and rooting, each level of growth regulator was replicated 12 times. After three weeks of culture from the initiation stage, the response of cultures on regeneration media was observed. The responses were evaluated for number of shoots and shoot height from the nodal sections of each of these commercial varieties. Assessment for rooting was six weeks after inoculation on rooting media. The number of roots was noted and average root length measured using a vernier calliper. To determine the optimal growth regulator for both experiments, analysis of variance was performed using GenStat edition 13 VSN international software. The mean number of responses were compared using Tukey's multiple range test $(\alpha=0.001)$.

\section{RESULTS}

Number of shoots. The number of shoots observed on different media treatments was significantly $(\mathrm{P}<0.001)$ different (Table 1$)$. The number of shoots was highest ( 3.67 shoots) when the varieties were cultured on MS media supplemented with $3 \mathrm{mg} \mathrm{l}^{-1}$ BAP singly, followed by a combination of $2 \mathrm{mg} \mathrm{l}^{-1}$ BAP and $0.5 \mathrm{mg} \mathrm{l}^{-1}$ KIN that yielded 3.33 shoots. The lowest (1.33) was observed on hormone free MS media. Across all treatments, variety KPF4 exhibited the highest shoot regeneration. The mean number of shoot of KPF 4 (3.39) was significantly $(\mathrm{P}<0.001)$ higher than for Yellow (2.43) and Small purple (1.89) (Table 1). The mean number of shoots for each of the varieties increased with increasing BAP 
concentrations in the MS media. This pattern was, however, not so when both BAP and KIN were added to the media except for KPF 4 (Table $1)$.

Shoot height. The mean height of shoots was significantly $(\mathrm{P}<0.001)$ highest $(3.08)$ when the varieties were cultured on MS media supplemented with a combination of $2 \mathrm{mg} \mathrm{l}^{-1} \mathrm{BAP}$ and $0.5 \mathrm{mg} \mathrm{l}^{-1} \mathrm{KIN}$ (Table 2). The lowest (1.542 $\mathrm{cm}$ ) was observed on MS media containing $3 \mathrm{mg}$ $\mathrm{1}^{-1} \mathrm{BAP}$ and $0.5 \mathrm{mg} \mathrm{l}^{-1} \mathrm{KIN}$. The response of KPF $4(2.7 \mathrm{~cm})$ was higher than for Small purple (1.77 $\mathrm{cm})$ and Yellow $(1.55 \mathrm{~cm}$ ) (Table 2) and (Fig. 1). Further, shoot height of KPF4 was highest (3.87 $\mathrm{cm})$ when cultured on MS media supplemented with a combination of $1 \mathrm{mg} \mathrm{l}^{-1} \mathrm{BAP}$ and $0.5 \mathrm{mg} \mathrm{l}^{-1}$ KIN. Shoot heights of Small purple $(3.50 \mathrm{~cm})$ and Yellow $(2.50 \mathrm{~cm})$ were highest when on MS media containing a combination of $2 \mathrm{mg} \mathrm{l}^{-1} \mathrm{BAP}$ and 0.5 $\mathrm{mg}^{-1} \mathrm{KIN}$. Whereas the lowest response for KPF4 $(1.50 \mathrm{~cm})$ was on MS media containing $3 \mathrm{mg} \mathrm{l}^{-1}$

TABLE 1. Number of shoots that regenerated on MS media supplemented with varying concentrations of BAP (singly) and in combination with $0.5 \mathrm{mg} \mathrm{l}^{-1} \mathrm{KIN}$

\begin{tabular}{|c|c|c|c|c|}
\hline \multirow[t]{2}{*}{ Treatment } & \multicolumn{3}{|c|}{ Passion fruit variety } & \multirow[t]{2}{*}{ Mean } \\
\hline & Small purple & Yellow & KPF 4 & \\
\hline $0 \mathrm{mg} \mathrm{l}^{-1} \mathrm{BAP}+0 \mathrm{mg} \mathrm{l}^{-1} \mathrm{KIN}$ & $1.25^{c}$ & $1.50^{\text {cd }}$ & $1.25^{\mathrm{e}}$ & $1.33^{e}$ \\
\hline $1 \mathrm{mg} \mathrm{l}^{-1} \mathrm{BAP}$ & $1.00^{d}$ & $2.50^{\mathrm{ab}}$ & $3.25^{b c}$ & $2.25^{\mathrm{cd}}$ \\
\hline $2 \mathrm{mg} \mathrm{l}^{-1} \mathrm{BAP}$ & $1.75^{\mathrm{bc}}$ & $2.25^{\mathrm{bc}}$ & $2.50^{\mathrm{cd}}$ & $2.17^{\mathrm{cd}}$ \\
\hline $3 \mathrm{mg} \mathrm{l}^{-1} \mathrm{BAP}$ & $3.25^{\mathrm{a}}$ & $3.00^{\mathrm{a}}$ & $4.75^{\mathrm{a}}$ & $3.67^{a}$ \\
\hline $1 \mathrm{mg} \mathrm{l}^{-1} \mathrm{BAP}+0.5 \mathrm{mg} \mathrm{l}^{-1} \mathrm{KIN}$ & $1.50^{c}$ & $2.25^{\mathrm{bc}}$ & $3.50 \mathrm{bc}$ & $2.42^{\mathrm{bc}}$ \\
\hline $2 \mathrm{mg} \mathrm{l}^{-1} \mathrm{BAP}+0.5 \mathrm{mg} \mathrm{l}^{-1} \mathrm{KIN}$ & $3.00^{\mathrm{a}}$ & $3.25^{\mathrm{a}}$ & $3.75^{\mathrm{ab}}$ & $3.33^{\mathrm{a}}$ \\
\hline $3 \mathrm{mg} \mathrm{l}^{-1} \mathrm{BAP}+0.5 \mathrm{mg} \mathrm{l}^{-1} \mathrm{KIN}$ & $1.50^{c}$ & $2.25^{\text {bc }}$ & $4.75^{\mathrm{a}}$ & $2.88^{b}$ \\
\hline * Mean & $1.89^{c}$ & $2.43^{b}$ & $3.39 a$ & \\
\hline
\end{tabular}

Means with the same letters in the columns (and row for * mean) are not significantly $(P>0.001)$ different according to Tukey's multiple range test

TABLE2. Shoot height for three varieties of passionfruit cultured on MS media supplemented with varying concentrations of BAP (singly) and when in combination with $0.5 \mathrm{mg} \mathrm{l}^{-1} \mathrm{KIN}$

\begin{tabular}{|c|c|c|c|c|}
\hline \multirow[t]{2}{*}{ Treatment } & \multicolumn{3}{|c|}{ Passionfruit variety } & \multirow[t]{2}{*}{ Mean } \\
\hline & Small purple & Yellow & KPF 4 & \\
\hline $0 \mathrm{mg} \mathrm{l}^{-1} \mathrm{BAP}+0 \mathrm{mg} \mathrm{l}^{-1} \mathrm{KIN}$ & $0.50^{\mathrm{e}}$ & $0.75^{d}$ & $3.75^{\mathrm{a}}$ & $1.67^{\circ}$ \\
\hline $1 \mathrm{mg} \mathrm{l}^{-1} \mathrm{BAP}$ & $1.75^{c}$ & $1.50^{\mathrm{b}}$ & $2.27^{c}$ & $1.84^{\mathrm{c}}$ \\
\hline $2 \mathrm{mg} \mathrm{l}^{-1} \mathrm{BAP}$ & $0.75^{\text {de }}$ & $2.25^{\mathrm{a}}$ & $2.50^{c}$ & $1.83^{c}$ \\
\hline $3 \mathrm{mg} \mathrm{l}^{-1} \mathrm{BAP}$ & $2.26^{b}$ & $1.12^{\mathrm{c}}$ & $1.75^{\mathrm{d}}$ & $1.71^{\mathrm{c}}$ \\
\hline $1 \mathrm{mg} \mathrm{l}^{-1} \mathrm{BAP}+0.5 \mathrm{mg} \mathrm{l}^{-1} \mathrm{KIN}$ & $1.50^{c}$ & $1.75^{\mathrm{b}}$ & $3.87^{\mathrm{a}}$ & $2.37^{b}$ \\
\hline $2 \mathrm{mg} \mathrm{l}^{-1} \mathrm{BAP}+0.5 \mathrm{mg} \mathrm{l}^{-1} \mathrm{KIN}$ & $3.50^{\mathrm{a}}$ & $2.50^{\mathrm{a}}$ & $3.25^{b}$ & $3.08^{\mathrm{a}}$ \\
\hline $3 \mathrm{mg} \mathrm{l}^{-1} \mathrm{BAP}+0.5 \mathrm{mg} \mathrm{l}^{-1} \mathrm{KIN}$ & $2.12^{b}$ & $1.00^{c}$ & $1.50^{\mathrm{d}}$ & $1.54^{\mathrm{cd}}$ \\
\hline${ }^{*}$ Mean & $1.77^{\mathrm{b}}$ & $1.55^{b}$ & $2.7^{\mathrm{a}}$ & \\
\hline
\end{tabular}

Means with the same letters in the columns (and row for * mean) are not significantly $(P>0.001)$ different according to Tukey's multiple range test 
BAP and $0.5 \mathrm{mg} \mathrm{l}^{-1} \mathrm{KIN}$; that for Small purple (0.5 $\mathrm{cm})$ and Yellow $(0.75 \mathrm{~cm})$ was on hormone free media ( $0 \mathrm{mg} \mathrm{l}^{-1} \mathrm{BAP}$ and $0 \mathrm{mg} \mathrm{l}^{-1} \mathrm{Kin}$ ) (Table 2).

Number of roots. Hormonal treatments incited root development differently in the three varieties (Table 3). Low levels of hormones did not induce or poorly induced root formation in Small purple; highest level of root induction in Small purple was observed with $1 \mathrm{mg} \mathrm{l}^{-1} \mathrm{NAA}$ and $0.5 \mathrm{mg} \mathrm{l}^{-1}$ BAP. Overall, the number of roots significantly $(\mathrm{P}<0.001)$ differed with the highest mean $(5.5$ roots) being observed on MS media supplemented with $3 \mathrm{mg} \mathrm{l}^{-1} \mathrm{NAA}$; while the lowest mean (1.92 roots) was on hormone free media (Table 3). Highest proliferation of roots in Yellow and KPF 4 were observed when the media was supplemented with $3 \mathrm{mg} \mathrm{l}^{-1} \mathrm{NAA}$. Therefore, the single media containing $3 \mathrm{mg} \mathrm{l}^{-1}$ NAA could be used across all the three varieties.

Length of roots. Generally, there was no clear relationship between NAA concentration and root length (Table 3). Greatest root length was observed for different varieties; $6.00 \mathrm{~cm}$ for Small purple with $1 \mathrm{mg} \mathrm{l}^{-1} \mathrm{NAA}$ and $0.5 \mathrm{mg} \mathrm{l}^{-1} \mathrm{BAP}, 4.50$

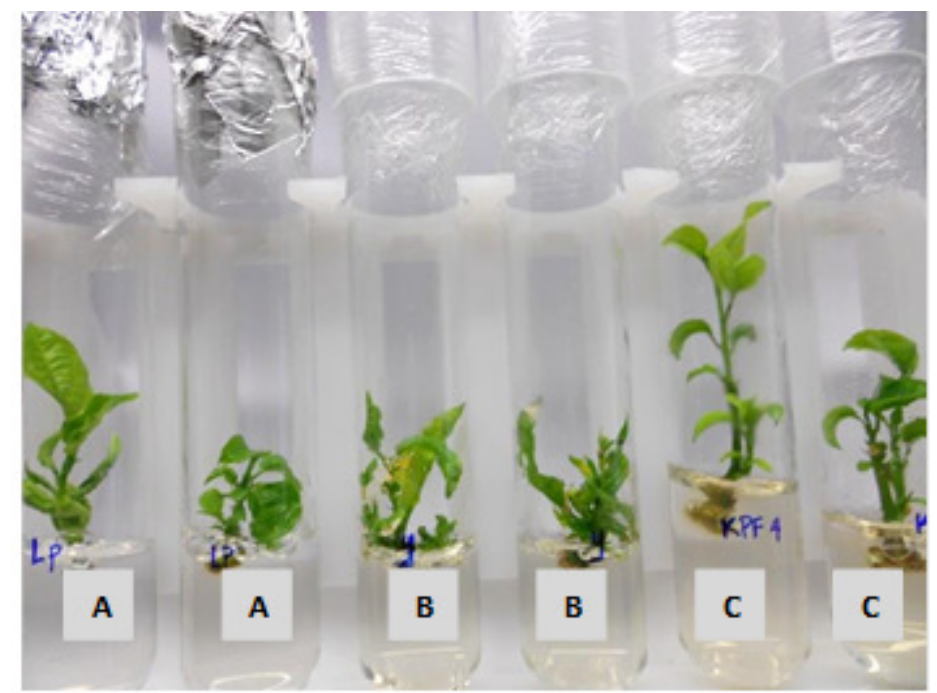

Figure 1. Shoot height induction in three passionfruit varieties on MS media supplemented with different hormones; (A) Small purple and (B) Yellow cultured on MS medium supplemented with $2 \mathrm{mg} \mathrm{l}^{-1} \mathrm{BAP}$ and $0.5 \mathrm{mg} \mathrm{l}^{-1} \mathrm{KIN}$; and (C) KPF 4 cultured on 1 $\mathrm{mg} \mathrm{l}^{-1} \mathrm{BAP}$ and $0.0 \mathrm{mg} \mathrm{l}^{-1} \mathrm{KIN}$

TABLE 3. Number of roots for three varieties of passionfruit growing on MS media supplemented with varying concentrations of NAA (singly) and when in combination with $0.5 \mathrm{mg} \mathrm{l}^{-1} \mathrm{BAP}$

\begin{tabular}{lcccc}
\hline Treatment & \multicolumn{3}{c}{ Passionfruit variety } & Mean \\
\cline { 2 - 4 } & Small purple & Yellow & KPF 4 & \\
\hline $0 \mathrm{mg} \mathrm{l}^{-1} \mathrm{NAA}+0 \mathrm{mg} \mathrm{l}^{-1} \mathrm{BAP}$ & $0.00^{\mathrm{e}}$ & $1.50^{\mathrm{de}}$ & $4.25^{\mathrm{b}}$ & $1.92^{\mathrm{e}}$ \\
$1 \mathrm{mg} \mathrm{l}^{-1} \mathrm{NAA}$ & $0.00^{\mathrm{e}}$ & $5.25^{\mathrm{c}}$ & $3.50^{\mathrm{c}}$ & $2.92^{\mathrm{c}}$ \\
$2 \mathrm{~m} \mathrm{l}^{-1} \mathrm{NAA}$ & $0.00^{\mathrm{e}}$ & $7.25^{\mathrm{b}}$ & $4.50^{\mathrm{b}}$ & $3.92^{\mathrm{b}}$ \\
$3 \mathrm{mg} \mathrm{l}^{-1} \mathrm{NAA}$ & $2.50^{\mathrm{d}}$ & $8.75^{\mathrm{a}}$ & $5.25^{\mathrm{a}}$ & $5.5^{\mathrm{a}}$ \\
$1 \mathrm{mg} \mathrm{l}^{-1} \mathrm{NAA}+0.5 \mathrm{mg} \mathrm{l}^{-1} \mathrm{BAP}$ & $8.50^{\mathrm{a}}$ & $1.25^{\mathrm{e}}$ & $1.50^{\mathrm{d}}$ & $3.75^{\mathrm{b}}$ \\
$2 \mathrm{mg} \mathrm{l}^{-1} \mathrm{NAA}+0.5 \mathrm{mg} \mathrm{l}^{-1} \mathrm{BAP}$ & $3.75^{\mathrm{c}}$ & $1.50^{\mathrm{de}}$ & $2.25^{\mathrm{c}}$ & $2.5^{\mathrm{d}}$ \\
$3 \mathrm{mg} \mathrm{l}^{-1} \mathrm{NAA}+0.5 \mathrm{mg} \mathrm{l}^{-1} \mathrm{BAP}$ & $4.50^{\mathrm{b}}$ & $1.75^{\mathrm{d}}$ & $2.25^{\mathrm{c}}$ & $2.83^{\mathrm{cd}}$ \\
\hline
\end{tabular}

Means with the same letters in the columns are not significantly $(P>0.001)$ different according to Tukey's multiple range test 


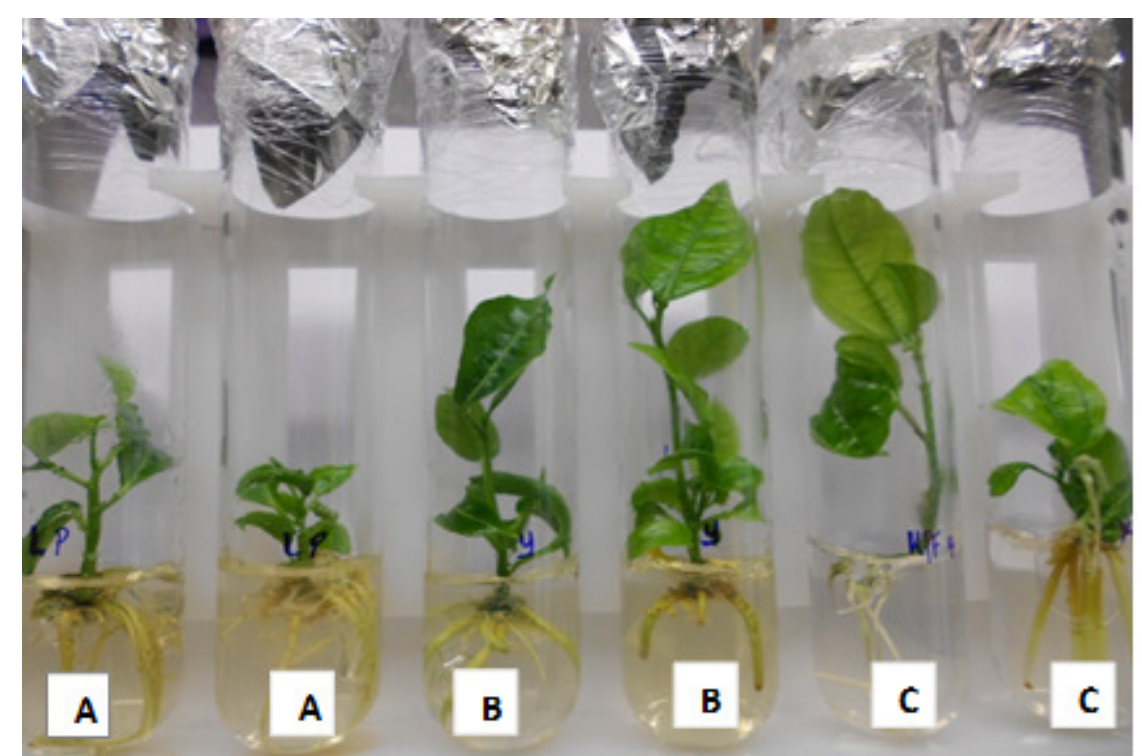

Figure 2. In vitro root development of three passionfruit varieties on MS media supplemented with $1 \mathrm{mg}^{-1} \mathrm{NAA}$ and $0.5 \mathrm{mg} \mathrm{l}^{-1} \mathrm{BAP}$ for A) Small purple and; hormone free media for B) Yellow and C) KPF 4

cm for Yellow with $1 \mathrm{mg} \mathrm{l}^{-1} \mathrm{NAA}$, and $4.50 \mathrm{~cm}$ for KPF 4 without any hormone supplementation (Fig. 2). On average, the lowest $(1.25 \mathrm{~cm})$ root length was observed with $3 \mathrm{mg} \mathrm{l}^{-1} \mathrm{NAA}$ and 0.5 $\mathrm{mg} \mathrm{l}^{-1}$ BAP were in use (Table 3 ). The length of roots of Small purple differed significantly from the other two cultivars. That is, the highest length $(6.0 \mathrm{~cm})$ was when cultured on MS media supplemented with $1 \mathrm{mg} \mathrm{l}^{-1} \mathrm{NAA}$ and $0.5 \mathrm{mg} \mathrm{l}^{-1}$ BAP, yet no roots were formed on hormone free MS media and that containing 1 , and $2 \mathrm{mg} \mathrm{l}^{-1}$ NAA (Table 3).

\section{DISCUSSION}

The highest shoot regeneration was in KPF 4, followed by Yellow and Small purple; displaying the phenomenon of the differences in variety response to in vitro culture media and conditions observed in plants (Drew, 1991; Arinaitwe, 2008; Marcin and Barbara, 2013). KPF 4 required lower concentrations of rooting hormone supplementation compared to the Small purple variety. This could be attributed to genetic predisposition and that different varieties respond differently to in vitro regeneration. Previous effort by Amugune (1993) indicated difficulties in regeneration of Yellow and Small purple passionfruit varieties.

A high concentration $\left(3 \mathrm{mg} \mathrm{l}^{-1}\right)$ of BAP induced high numbers of shoots. However, this was not so when in combination with $0.5 \mathrm{mg} \mathrm{l}^{-1}$ Kinetin. This may be attributed to the fact that in vitro plants require a specific concentration of hormones to stimulate different growth cycles. This can be observed for all varieties when growing on MS media containing $2 \mathrm{mg} \mathrm{l}^{-1} \mathrm{BAP}$ and $0.5 \mathrm{mg} \mathrm{l}^{-1} \mathrm{KIN}$. Rashid et al. (2002) also noted that addition of different levels of growth regulators in culture medium increases plantlet regeneration frequency. NAA was observed to be more efficient at increasing root induction; on the contrary BAP depressed root induction especially in Yellow and KPF 4 passionfruit varieties. In general, increase in levels of NAA increased root proliferation up to $3 \mathrm{mg} \mathrm{l}^{-1} \mathrm{NAA}$, thus indicating MS with $3 \mathrm{mg} \mathrm{l}^{-1} \mathrm{NAA}$ as the single best media for all the three varieties. Similarly, Madhulatha et al. (2004) used BAP and KIN in combination and found that beyond $200 \mathrm{mg} \mathrm{l}^{-1}$, the number of shoots per plant fell from 5.05 from 14.12, indicating an adverse effect of cytokinins on bananas shoot proliferation. The levels of cytokinins used in this study (BAP and KIN) on 
passionfruit were much lower compared to the levels of $1.10-22.50 \mathrm{mg} \mathrm{l}^{-1}(5-100 \mu \mathrm{M})$ of BAP used that have used in banana micropropagation (Sadik et al., 2015)

During rooting, the interaction of auxins and cytokinins on root numbers and development was observed when the Small purple variety responded more at $1 \mathrm{mg} \mathrm{l}^{-1} \mathrm{NAA}$ and $0.5 \mathrm{mg} \mathrm{l}^{-1}$ Kinetin. Akwatulira et al. (2011) emphasised that application of auxins like NAA is beneficial to root system development. Interestingly, more roots for Yellow and KPF 4 passionfruit varieties were observed when growing on hormone-free media (Table 3). A similar observation was noted by Drew (1991) for Yellow variety. Higher concentrations of hormones have been found to be inhibitory to some development cycles (Gaspar et al., 1996). This could have been the case for Yellow and KPF 4 passionfruit varieties at high concentrations of NAA and Kinetin as shown in this study. Overall, this study has shown successful regeneration with respect to number of shoot and shoot height on MS media, supplemented with $2 \mathrm{mg} \mathrm{l}^{-1}$ BAP and $0.5 \mathrm{mg} \mathrm{l}^{-1}$ KIN.

\section{CONCLUSION}

This study developed optimum medium for three commercial passionfruit varieties of Small purple, Yellow and KPF 4. Different media were observed to be appropriate for shoot regeneration $\left(3 \mathrm{mg} \mathrm{l}^{-}\right.$ $\left.{ }^{1} \mathrm{BAP}\right)$, shoot elongation ( $2 \mathrm{mg} \mathrm{l}^{-1} \mathrm{BAP}$ and 0.5 $\left.\mathrm{mg} \mathrm{l}^{-1} \mathrm{KIN}\right)$, and root induction ( $\left.3 \mathrm{mg} \mathrm{l}^{-1} \mathrm{NAA}\right)$ across all the three varieties. This is not withstanding the small differences in response to in vitro micropropagation between varieties. This eliminates the rigorous procedures that would be envisaged while dealing with individually different protocols as was described for Small purple (Siripatr et al., 2011) and Yellow (Biasi et al., 2000).

\section{ACKNOWLEDGEMENT}

The authors thank the Africa Biosciences Challenge Fund (ABCF), managed by the BecAILRI Hub, for providing the fellowship and financial support. The administrative and technical staff at BecA-ILRI Hub, Kenya, and staff at Makerere University Tissue Culture Laboratory at Kabanyolo were very supportive.

\section{REFERENCES}

Akwatulira, F., Gwali, S., Okullo, J.B.L., Ssegawa, P., Tumwebaze, S.B., Mbwambo, J.R. and Muchugi, A. 2011. Influence of rooting media and IBA concentration on rooting and shoot formation of Warburgia ugandensis stem cutting. African Plant Science 5: 421-429.

Akin-Idowu, P.E., Ibitoye, D.O. and Ademoyegun, O.T. 2009. Tissue culture as a plant production technique for horticultural crops. African Journal of Biotechnology 8: 3782-3788.

Amugune, N.O., Gopalan, H.N. and Bytebier, B. 1993. Leaf disc regeneration of passion fruit. African Crop Science Journal 2: 99-104.

Arinaitwe, G. 2008. An improved Agrobacterium mediated transformation method for banana and plantain (Musa spp.). PhD thesis, Catholic University of Leuven, Belgium. 153pp.

Biasi, L.A., Falco, M.C., Rodriguez, P.M., Beatriz, M. and Mendes, J. 2000. Organogenesis from internodal segments of yellow passion fruit. Scientia Agricola 57: 661-665.

Brown, D.C.W. and Thorpe, T.A. 1995. Crop improvement through tissue culture. World Journal of Microbiology and Biotechnology 11: 409-415.

Carrero, D.A., Melo, D., Uribe, S, and Wyckhuys, K.A.G. 2013. Population dynamics of Dasiops inedulis (Diptera: Lonchaeidae) and its biotic and abiotic mortality factors in Colombian sweet passionfruit orchards. Journal of Pest Science 86: 437-447.

Drew, R. A. 1991. In vitro culture of adult and juvenile bud explants of Passiflora species. Plant Cell, Tissue and Organ Culture 26: 2327.

Gaspar, T. Kevers, C., Penel, C., Greppin., H., Reid, D. and Thorpe, T.A. 1996. Plant hormones and plant growth regulators in plant tissue culture. A review. In Vitro Cell and Development Biology 32: 272-289.

George, E.F. 1996. Plant propagation by tissue culture. Part 2. In practice. Exegetics Limited, Edington, U.K. pp. 65-113.

Joy, P.P. 2010. Passion fruit (Passiflora edulis Sims): Passifloraceae. Pineapple Research 
Station (Kerala Agricultural University), Vazhakulam-686 670, Muvattupuzha, Ernakulam District, Kerala, India.

Madhulatha, P., Anbalagan, M., Jayachandran, S., Sakthivel, N. 2004. Influence of liquid pulse treatment with growth regulators on in vitro propagation of banana (Musa spp. AAA). Plant Cell Tissue Organ and Culture 76: 189192.

Marcin, O. and Barbara, T. 2013. Progress in micropropagation of Passiflora spp. to produce medicinal plants: A mini-review. Revista Brasileira de Farmacognosia 23: 937947.

Mbaka, J.N., Waiganjo, M.N., Chegeh, B.K., Ndungu, B., Njuguna, J.K., Wanderi, S., Njoroge, J. and Arim, M. 2006. A survey of the major passion fruit diseases in Kenya.Tenth Biennial KARI Proceedings. Nairobi Kenya.

Morton, J.F. 1987. Passionfruits In: Fruits of warm climates. Miami, FL. pp. 320-328. https:// hort.purdue.edu/newcrop/morton/passion fruit.html

Murashige, T. and Skoog, F. 1962. A revised medium for rapid growth and bioassays with tobacco tissue culture. Physiologia Plantarum 15: 473-497.

Nehra, S.A. and Kartha, K.K. 1994. Meristem and shoot tip culture: Requirements and applications. In: Plant cell and tissue culture. Vasil, I. and Thorpe, T.A. (Eds.). Dordrecht, Netherlands: Kluwer Academic Publishers. pp. 37-70.

Rashid, H., Ghani, R.A. and Chaudhry, Z. 2002. Effect of media, growth regulators and genotype on callus induction and regeneration in wheat (Triticum aestivum). Biotechnology 1: 49-54.
Sadik, K., Arinaitwe, G., Rubaihayo, P.R. and Mukasa, S.B. 2015. TDZ and 4-CPPU induce embryogenic response on scalps of recalcitrant East African Highland Banana. Journal of Agricultural Science 7(8): 1-10.

Senyonyi, T. 2014. The wealth in passion fruit farming. Promoting farmer entrepreneurship. Agri-hub Uganda. www. Apf-uganda.ning. com. Published February 142014.

Ssemwanga, F. 2007. Study for fruits sub-sector (pineapple, passion fruits, mangoes), Ssemwanga Consulting Group - Kampala Uganda. http://www.fituganda.com/ manage/ download/atm/marketreports/subsector studyfruits.pdf. Accessed on February 09 2016.

Siripatr, P., Sarut, T., Pissawan, C. and Narongchai, P. 2011. Efficient shoot regeneration from direct apical meristem tissue to produce virusfree purple passion fruit plant. Crop Protection 30: 1425-1429.

Wangungu, C.W., Mwangi, M., Gathu, R. and Muasya, R. 2014. Good orchard maintenance and agronomic practices as working components in management of dieback disease on passion fruit (Passiflora sp.) in Kenya. Annual Research and Review in Biology 4: 1397-1405.

Wesonga, J.M., Losenge, T., Ndung'u, C.K., Ngamau, K., Njoroge, J.B.M., Ombwara, F.K. and Agong, S.G. 2002. Sustainable horticultural production in the tropics. Proceedings of the Second Horticulture Seminar on Sustainable Horticultural Production in the Tropics, August 6th - 9th 2002. Jomo Kenyatta University of Agriculture and Technology, JKUAT, Juja, Kenya. 